\title{
Urban Youth Unemployment in Africa: Whither Socio-Economic Problems
}

\author{
Stephen Mago (PhD) \\ University of Fort Hare, P. Bag X1314, Alice, 5700, South Africa \\ E-mail: stepmago@gmail.com
}

\section{Doi:10.5901/mjss.2014.v5n9p33}

\section{Abstract}

This article investigates the likely future effects of urban youth unemployment on socio-economic and political fundamentals in Africa. African countries face a daunting challenge of high urban youth unemployment. The challenge of high levels of urban youth unemployment in Africa need urgent attention. Following a qualitative research methodology, this paper investigates the effects of urban youth unemployment on the society and economy of Africa. Results show that Africa's levels of urban youth unemployment are on the increase and are climbing into crisis levels. This paper recommends that African governments need to put strategies in place to stem the urban youth unemployment tide. Regional integration strategies could also be designed to incorporate solutions to the teething challenge.

Keywords: Youth, Youth unemployment, urban unemployment, socio-economic problems, Africa.

\section{Introduction}

Youth unemployment is estimated to be twice more than unemployment among adults. Kararach et al.(2011) state that Africa is facing a 'youth bulge'. However, it is not expected that it reverses the benefits of the 'demographic dividend' envied by developed countries that are facing ageing populations. According to ILO(2013), 90\% of the global youth population lives in developing countries thus posing a 'scarring' challenge. Figure 1 below gives a self-explanatory summary of unemployment and unemployment rates of youth at global level between 1991 and 2013. The global unemployment rate averages $12 \%$ and the unemployed youth reaches about 75 million. This is a scary global trend.

Figure 1: Global Youth Unemployment and Unemployment rates, 1991 to 2013

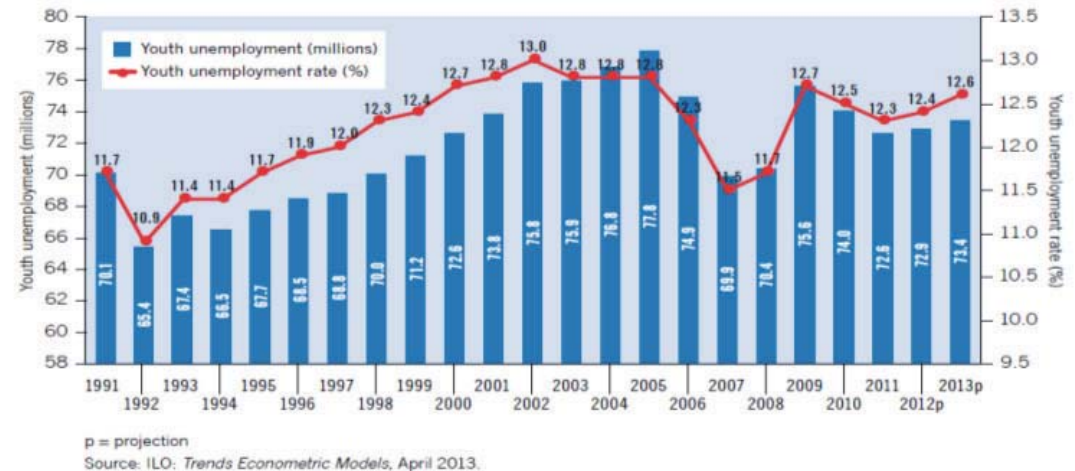

Source: ILO $(2013,8)$

\subsection{Snapshot of Youth Unemployment rates in Africa}

Youth unemployment is a crucial problem in Africa and other developing countries (Simiyu and Sambu, 2012). Most of the African countries' rates of youth unemployment go above the global average rate of $12 \%$. For example, Sierra Leone shows the highest rate of $60 \%$. Table 1 below summarizes the rates for selected African countries: 
Table 1: Rates of Youth Unemployment for selected African Countries

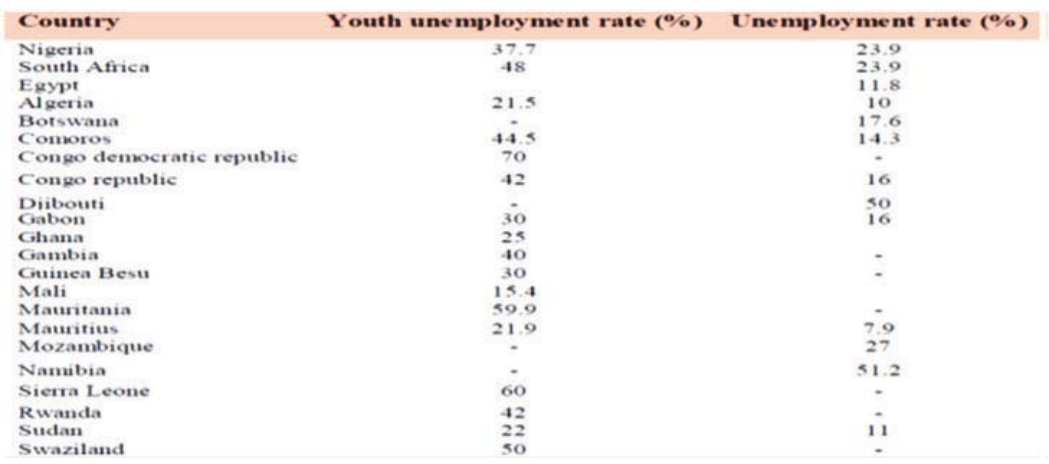

Source: Araya (2012:3)

Urban youth unemployment remains a major challenge for Africa. Sommers (2003:28) observes that "Large, swelling African cities are awful places." For example, South Africa's urban population has shifted from an average of $30 \%$ to $62 \%$ (Gordhan, 2013). UNESCO (2003: 7) states that "Youth unemployment has its own unique problems and the programs and schemes designed to help young people find jobs have inherent advantages and disadvantages." A number of strategies ought to be developed to help the youth out of unemployment. Approaches such as "enterprise-based youth employment promotion"(ILO, 2003) could be utilized. The Youth Business International (YBI), a member of the UN/LO/World Bank Policy Network on Youth Network, is one way of bringing the youth together. YBI works as a platform for coming up with "innovative approaches to the promotion of youth entrepreneurship"(Chambers and Lake, 2001: 9).

The causes of urban youth unemployment include rural-urban migration (Gordhan, 2013) that leads to urban explosion, spatial disparities caused by apartheid urban planning leading to spatial related unemployment (Hall,1997), lack of government support (Kezban, 2008), global slowdown (ILO, 2008), lack of youth policy implementation (Department of Social Development (DSD) $(2007,2008,2009)$; and Presidency of South Africa (2009). Other causes are poor education or defective education systems, lack of skills among the youth, lack of work experience, and unwillingness to work by the youth, failure of the informal sector etcetera (see for example Langevang \& Gough, 2009 and Parkes \& Conolly, 2011).

Regrettably, urban youth unemployment leads to unwanted outcomes such as crime, 'youth gangism', poverty, violence, juvenile delinquency, substance abuse, stress and depression, suicides, family instability, lack of self-esteem, HIVIAIDS and other related problems (see for example Hall, 1997; Hunter, 1998; Manning \& Junankar, 1998; Kahraman, 2011; Pervaiz et al., 2012 and Wubie, 2012). Solutions to this problem could be through government intervention. Partnerships with the private sector and other organizations (such as Non-governmental Organizations-NGOs) could also help.

\section{Theoretical Framework}

A number of theories provide a plausible understanding of urban youth unemployment: the Neo-Classical theories of employment (Jubenkanda, 2003; Sembonja, 2007; ILO, 2010; Kahraman, 2011), Human capital theory (Kahraman, 2011), and mismatch theory (Kahraman, 2011). Neo-Classical theories of employment are favoured by most economists to explain the employment/unemployment conditions. From the perspective of neo-classical labor economists, unemployment is categorized into voluntary, involuntary, technological, demand deficiency (Jubenkanda, 2003), structural, frictional, cyclical (Sembonja, 2007; ILO, 2010) and seasonal (ILO, 2010). Total unemployment situation is a combination or a total sum of unemployment and underemployment.

Voluntary unemployment is when people choose not to work at the prevailing market wage rate. The involuntarily unemployed prefer leisure or other activities to the available jobs. In South Africa, the social welfare system that remunerates young girls who are single parents has been blamed for encouraging voluntary unemployment among young women. This has in a way contributed towards a higher rate of female youth unemployment. Voluntary unemployment may also contribute to the willingness to stay unemployed in order to move from one job to the next or when school leavers move from college or university to their first job. 
Involuntary unemployment arises when qualified and able bodied people fail to get jobs at the prevailing wage rates. Keynes' General Theory (Jubenkanda, 2003) posits that involuntary unemployment is a product of coordination failures. It can be regarded as unemployment caused by deficiency of effective demand for labor. Coordination failures also result from the disconnection that exists between universities and industry. As a way of trying to address the problem, some universities have introduced internship programs. Some of the programs are driven by the government of South Africa. The programs involve university students getting attached to an organization for a specified period so as to gain practical work skills. An example is the Goega Industrial Zone internship program in the Eastern Cape Province of South Africa.

Technological unemployment results from a shift from labor-intensive to capital-intensive production systems. Some critics have advanced that technological unemployment has led to massive global unemployment especially among the young people (see for example Jubenkanda, 2003). Hi-tech production systems have replaced non-skilled workers. In the agricultural sector, the use of machinery has reduced the need for large numbers of workers needed for planting, weeding, watering and harvesting. Human labor is fast getting replaced by better productive methods hence throwing millions of people into unemployment. The industry is opting for technological production methods because unskilled labor is expensive in South Africa. Clark (2012) wrote about Schussler's report in line with unskilled labor:

\begin{abstract}
"According to the $11^{\text {th }}$ UASA Employment Report released by economists Mike Schussler on Friday, the employed unskilled workers in South Africa, in comparison with other countries surveyed are being paid too much. This effectively means that it is too expensive to employ for what they bring in terms of skills. ...Further, the lower-level worker in the government sector is paid about $18 \%$ too much."(p1).
\end{abstract}

With the spate of industrial actions in the South African mining sector and other sectors of the economy, research has shown that unskilled labor is very active in strikes. The unfortunate Marikana incident resulted in the death of miners who were on industrial action. This has made it unsafe to employ people who are likely to fight the employer. Consequently, employers opt for machinery and skilled labor. Skilled labor is so professional that the probability of it going on industrial action is very low.

Demand deficiency unemployment results from a situation where the demand for goods declines thus forcing manufacturers to downsize their operations. As a cost-cutting strategy, they will reduce the labor force thus creating unemployment.

Structural and cyclical unemployment are viewed from an economic theory perspective as disequilibrium scenarios (Sembonja, 2007) since they imply excess supply of labor on the labor market. Under this category the causes of unemployment could be determined as lack of employability among the youth, inadequate job creation and lack of youth entrepreneurs. Structural unemployment can be explained by the mismatch theory. The theory argues that failure of coordination between the educational institutions and industry creates a permanent skills gap that makes school leavers unemployable. Lack of employability means that the school-leavers do not have the skills required by the labor market. What then needs to be done is to create a strong partnership between employers and educational institutions. This will help them to work together in producing labor market candidates that are relevant.

Many authors (see for example National Treasury, 2011; Bhorat, n.d.; ILO, 2013) agree that the South Africa's education system does not adequately prepare school-leavers for the job market. School leavers lack relevant education and training that allow them to fit into the labor market. Structural constraints are also faced by first-time job seekers since employers opt for the experienced employees. According to ILO (2010), young employees are the 'last in' as employers prefer the experienced, and they are the 'first out' as employers prefer to keep adult employees. This becomes a 'nightmare' for the youth. Job scarcity, unfortunately, affects young people in the majority of cases (ILO, 2013). They are the most vulnerable in the labor market. The UN News Centre (2013) warns in its report entitled "World's Youth Facing Worsening Unemployment" that the world's youth is becoming more vulnerable and the youth unemployment rate is increasing from year to year. ILO (2013) confirms that world youth unemployment rate is currently at $2.4 \%$. Unemployment disconnects the youth from the society. "Disconnected youth" refers to the young people who are neither in employment nor in education (Guillermo et al., 2012).

Cyclical unemployment is caused by business cycles. When business activity decreases, productivity will decline hence causing layoffs. Conversely, employment increases when there is a business boom. During the recession phase of the business cycle, cyclical unemployment occurs (Jubenkanda 2003). For example, during the Great depression of the 1930s, cyclical unemployment reached about $25 \%$.

Frictional unemployment results from job changes. When a worker moves from one job to the next, there is a time when they will be temporarily out of employment. It also includes young people who are hunting for their first jobs-the time 
that elapses when moving from college/university to the first job. "Frictional unemployment is regarded to be as inevitable and, at least in part, desirable" (Jubenkanda, 2003:138). It is desirable in the sense that the workers will be moving to take up better jobs.

\subsection{Causes and effects of urban youth unemployment}

A large body of literature discusses the causes and effects of youth unemployment (see for example Fatoki and Chindoga, 2012; Ajaegbu, 2012; Pervaiz, 2011). The causes include urban expansion (due to rural-urban migration), slow urban development, slow economic growth (leading to low job creation), mismatch between university or college education and the labour market requirements. Causes of unemployment can be explained by the two causal categories. From economic theory, the causes are classified into supply-side and demand-side explanations.

\subsubsection{Supply-side and Demand-side Explanations}

Supply refers to the ability and willingness to provide a good service. From a labour market perspective, supply involves the provision of labour hours. Rural-urban migration increases the supply of labour in urban areas (Ramcharan, 2004). The vast majority of young people who migrate to urban areas will be seeking for employment. The rural labour market does not have enough jobs that can meet the demand by young people. This deficiency can be explained by Lipton's urban bias theoretical explanation. According to Lipton's notion of 'urban bias', there is a tendency to favour urban areas with developmental resources than rural areas. Resources are therefore directed towards the development of urban areas. This explanation is also captured by the centre-periphery argument of uneven development between regions or countries. Agricultural activities dominate the rural economies but many young people do not favour agriculture as a source of employment. They prefer to work in the urban centres thus instigating rural-urban migration. Consequently, urban explosion is experienced causing a 'youth-bulge'. Sembonja (2007) argues that utter neglect of the rural areas pushes young people in large numbers to urban areas.

Other than rural-urban migration, urban population growth is also responsible for growth of labour supply that outstrips demand. In South Africa for example, the World Bank(2012) reports that urban population growth is at 1.9\% per annum as compared to $-0.1 \%$ in the rural areas. This points to the effect of rural-urban migration on urban population growth. The supply of labour is far outstripping demand or the supply of jobs (job creation). The World Bank also estimates that the rate of urbanization is at $1.2 \%$ (2010 estimate).

Demand-side explanations can be used to determine the causes of unemployment. This entails the lack of coordination between the educational system and industry (job market). Many school- leavers fail to secure employment. Under-development in the rural areas ignites rural-urban migration hence young people migrate in large numbers to the urban areas in search of employment. In South Africa, Johannesburg is a prime destination for young job seekers. The Global Financial Crisis (GFC), industrial actions and other macroeconomic conditions have slowed down production especially in the mining sector. This has seen many people losing their jobs thus contributing towards unemployment.

\section{The Problems of Urban Youth Unemployment}

Urban youth unemployment creates socio-political and economic problems in urban societies. The socio-political problems include crime, violence, substance abuse, prostitution, 'gangism' and many others (Carmichael and Ward, 2000). Samara (2005) carried out a research in Cape Town and established that unemployment and marginalisation among the youth creates a threat to society.

\subsection{Social problems}

Social disorder is viewed as a result of the unemployed who are disappointed and discouraged. Samara (2005) also established that criminologists argue that the young people are very vulnerable to crime but at the same time they are involved in criminal activities. The main push factor of criminality among the urban youth is high unemployment. Young urban people are forced by circumstances to indulge in violence, drug abuse, prostitution and 'gangism'. Biased urban planning, dating back to the apartheid era, created spatial mismatch which has contributed to high unemployment among black youths. This, as explained by spatial and employment location theories (Hall, 1997), has accused location-related unemployment. Young people located in black townships may not have full access to job opportunities. For example, in South Africa, large black townships such as Soweto (in Johannesburg), Mitchell's Plain and Khayelitsha in Cape Town 
(Samara, 2005) and Mdantsane (in East London) have high rates of youth unemployment. The young people in these areas are known for being involved in a number of deviant activities that threaten social order.

Hall (1995) posits that urban youth unemployment is associated with high crime rates, poverty and other social problems. Violent and criminal lifestyles (Kouaouci, 2004; Parkes and Conolly, 2011) become common among the young people. Ajaegbu's (2012) article entitled "Rising Youth Unemployment and Violent Crime in Nigeria" found out that there is a strong association between urban youth unemployment and violent crimes such as murder, kidnapping and armed robbery. In Nigeria, 'Kidnappings are on the increase across Nigeria and the unemployed youths view 'the business' as lucrative" (Ajaegbu, 2012:317). Such behaviour has been driven by chronic youth unemployment (Kouaouci, 2004; Nwokwu, 2013). Furthermore, "the urban youth have shifted to Cybercrime popularly known as '419"' (Nwokwu, 2013). The intelligent young people who fail to secure employment use technology to hack private bank accounts and effect money withdrawals or transfers. Such activities have led to set-backs in economic development in the country. Martins et al., (2013) carried out a study in Baltimore on youth aggressive/disruptive behaviour and established that it is associated with problem gambling. Problem gambling is also perverse among unemployed young people as a way of buying time or making a living. Gambling is addictive and is likely to keep the youth unemployed thus worsening the unemployment rate. It is also associated with aggressive behaviour and violence.

Below is an e-mail received from Ndhlovu (a Senior Economics lecturer in the UK) that helps to explain the behaviour of South African urban youth who fail to secure employment. He wrote; "Well I've been telling every English person who questions me that this behaviour is not typical in SA. Izikhothane are a group of crazy kids/gangs from Jozi(referring to Johannesburg), particularly Soweto. In fact, the ones I saw in Soweto were not kids, more like young tsotsis(criminals) who buy expensive clothes out of proceeds of their ill-gotten loot. They compared and burnt the clothes to demonstrate that they could afford to do that. They dressed in colourful and expensive clothes, but colours which young and 'happening' South African kids wouldn't wear. The name Izikhothane doesn't exist in Zulu. In Zulu we have "oskhotheni" which is used particularly in Kwazulu Natal (KZN) to refer to young boys who don't attend school but hang around the neighbourhood smoking and robbing people. These boys also dress in expensive clothes but nothing that draws attention to them. They also wear your Allstars and Dikkies. They would never burn their clothes like "izikhothane" do. They treasure their clothes too much, particularly since they know how dangerous and precarious it was for them to get the money to buy the clothes." As implied in this email, unemployed youths have embraced a violent lifestyle as a way of coming to terms with their situation.

\subsection{Political Problems}

There is also a close association between urban youth unemployment and political instability. Young people are a dynamic segment of the population in each and every country. They are politically active. In Nigeria, Nwokwu $(2013,5)$ states that "The unemployed youths have become political thugs and blood-thirsty hoodlums at the disposal of the politicians." High unemployment among the youth exposes then to abuse by politicians who engage them in anti-social and clandestine political activities. In Zimbabwe, the young people were also used for political 'thuggism' especially during the 2008 elections. South Africa, with a youth unemployment rate of $48.2 \%$ ( Business Report, 2013) is sitting on a 'ticking bomb' because the patience of the young people seems to be running out. According to Blumenfeld (2012), the Democratic Alliance (DA) is using youth unemployment as a campaigning tool to mobilise young people against the ruling party-the African National Congress (ANC).

\subsection{Economic Problems}

Curtain (2004) expresses that investing in young people has notable macro and micro-economic benefits. From the Human capital Theory's perspective, the development of young people through education and training has got resounding promises as their skills are developed to foster economic growth and development. For South Africa and other African countries, there is a large pool of school-leavers who are seeking employment on the job market. This has created a bulge of young unemployed graduates that is worrying. Ndhlovu and Spring (2013:1) put it as follows: "A bulge of better-educated young people of working age is entering the job market and birth rates are beginning to decline. As the proportion of working-age people to dependents rises, growth should get a boost." The New Growth Path (NGP) of the South African government's major targets are to invest heavily in education, development of skills(especially scarce skills) and development of infrastructure. Skills among the young people are lacking. This can be explained by the mismatch theory of employment. It argues that unemployment can be caused by a mismatch that exists between the training offered and the jobs that are available on the job market. This could be due to lack of coordination between industry and 
educational institutions.

\section{Possible Solutions}

Urban youth unemployment is a multifaceted problem that requires a multipronged strategy. There is no one-size fits all strategy to fight urban youth unemployment. Many countries have approached the problem of youth unemployment differently mainly because of the different conditions, causes and effects. As discussed earlier, the severity of the problem is deeper in developing countries hence their governments need to approach urban youth unemployment with the seriousness it deserves. The ILO acts as an overall global manager of employment issues. ILO acts as a reference organization for all countries in the world. Its strategies tend to be followed by all since they are experts in labor issues. Strategies to fight urban youth unemployment in Africa could include correction of the defective education system, promotion of skills development among the youth, encouraging the young people to be innovative, youth entrepreneurial programs, rural development to stem rural-urban migration, encouraging the private sector to employ young people, job creation and government support.

In Southern Africa, South Africa's educational system is defective in the sense that it does not adequately prepare school-leavers for absorption into the labor market. The 2013 budget speech pointed out that about 1 million young people leave school annually but some are unemployable. At the same time, the economy is not creating enough jobs to match the supply from educational institutions. Due to the weak educational system, skills development among the young people needs urgent attention. School-leavers do not have skills that are required by the labor market since they do not have time to engage with industry. In this regard, the solution could be to intensify internship or industrial attachment programs so as to expose the learners to the real labor market.

Young people could also be encouraged to be innovative. The ILO organizes youth entrepreneurship programs that can help the young people to start their own businesses. This will transform them from job seekers to job creators. The development of an entrepreneurial culture among the youth will have an effect of deflating the urban youth unemployment bulge.

Another strategy could be promotion of rural development so as to stem rural-urban migration. Young people migrate from rural areas in search of jobs that are not presented in the rural areas. Rural areas could be developed to provide jobs and discourage migration to urban areas. The government could put strategies in place to encourage job creation in the rural areas so as to stop or actually reverse the 'rural-urban tide'.

The private sector should also be encouraged to employ young people. The South African government for example, recently announced the wage-subsidy program that is aimed at encouraging employment of young people. Employees who absorb young job seekers will get a subsidy form the government. This policy direction is likely to reduce urban youth unemployment. The National Treasury(2011:10) states that "Overall we project that a youth employment subsidy could subsidise more than 423000 new jobs for less-skilled young people over three years, at a cost of R5 billion in tax expenditure, with net job creation of 178000 . This would make an important contribution to creating decent jobs for young people and alleviating youth unemployment." However, the wage subsidy program has been criticized because it may cause adult unemployment thus creating another problem.

Job creation must be a priority if South Africa is to alleviate unemployment among the urban youth. The private sector could be supported through government subsidy programs, to create jobs for the economy. Government support could come in form of job creation policies, creation of an environment that is conducive for investors to do business in the country. Government could put in place programs that attract investors with the potential to create jobs in South Africa. The government could also support youth skills development programs that are meant to improve their employability status.

\subsection{Regional integration and Urban Youth Unemployment}

Regional integration (RI) involves the coming together of nations for joint socio-economic cooperation to fight unemployment and poverty, among other things. Africa needs robust regional integration strategies to take advantage of the demographic dividend. The youths have the potential to drive the economy of Africa but they suffer from the problem of acute unemployment. RI arrangements allow for the movement of labour thus making the youths to have access to employment opportunities in the region. For example, the ECOWAS arrangements allow the youths to seek employment in any of the ECOWAS states using the ECOWAS passport. Kararach et al. (20110 strongly suggest that regional integration could be the way forward for Africa to deal with the youth bulge. Concerted effort is required from regional members so as to deal with the challenge. 


\section{Conclusion}

The challenge of urban youth unemployment is profound the world over. Urban explosion in most developing countries has been blamed for urban youth unemployment. As urban areas grow, the pace of growth is failing to match with urban economic growth hence the creation of jobs also fails to meet the demand for jobs especially by young people. World statistics show that the youth unemployment rate is more than double the adult rate of unemployment. This feature is universal. Urban youth unemployment has become a 'ticking bomb' for Africa which has social, political and economic implications. However, strategies could be put in place by governments and other stakeholders to stem the tide. At continental level, regional integration is seen as a strategy that could help to solve the problem of urban youth unemployment by easing the urban 'youth bulge'.

\section{References}

Ajaegbu Okechukwu Odinaka. (2012). Rising Youth Unemployment and Violent Crime in Nigeria. American Journal of Social Issues \& Humanities Vol.2(5) pp. 315-321. and Employment Ministers, Paris, $26-27$ September 2011. Retrieved April 5,2013.

Araya Mesele. (2012). Generating Jobs for the Youths: A Priority agenda for Africa. University of Bengamo. Retrieved February 25, 2013 from www.adapt.it.

Bhorat H (n.d). Youth Employment Issues in Post-apartheid South Africa. PowerPoint presentation. Development Policy Research Unit, University of Cape Town. Retrieved March 12,2013 from www.commerce.uct.ac.za/dpru.

Blumenfeld Jesmond. (2012). Understanding South Africa's Youth Unemployment Problem. Politicsweb. Retrieved April 22, 2013 from www.politicsweb.co.za/politicsweb/v...

Business Report. (2013 February 3). Youth Unemployment needs a Jump-start. Retrieved April 5, 2013 from www.iol.co.za/youthunemployment-ne... 20-04-2013.

Carmichael Fiona \& Robert Ward. (2000). Youth unemployment and crime in the English regions and Wales, Applied Economics, 32:5, 559-571.

Chambers, Rachel; Lake, Anna. (2001). Youth Business International: Bridging the gap between unemployment and self-employment for consultative conference, Pretoria: South Africa.

Changing Times, Summary Report of UN World Youth Report, UNDESA, New York.

Clark Jeanette. (2012). Unskilled Labour in South Africa too Expensive for the Country. Moneyweb. Retrieved 2013April 23 from www.moneyweb.co.za/moneyweb-politic....

Countries, Istanbul, 9-13 May 2011. Retrieved March 24, 2013 from http://www.ilo.org/empelm/info/docs/WCMS_153868/lang-en/index.htm

Department of Social Development (DSD). (2007). National Youth Development Strategy. Pretoria. Retrieved April 15, 2013 from http://www.dsd.gov.za/index.php?option=com_content\&task=view\&id=131\&ltemid=8

Department of Social Development (DSD). (2008). The State of Youth Work in South Africa. Pretoria. Retrieved April 15, 2013 from http://www.dsd.gov.za/index.php?option=com_content\&task=view\&id=131\&ltemid=8

Department of Social Development (DSD). (2009). Address by Minister of Social Development. Pretoria. Retrieved April 15, 2013 from http://www.dsd.gov.za/index.php?option=com_content\&task=view\&id=131\&ltemid=8

Fatoki $\mathrm{OO}$ and Chindoga L. (2012). Triggers and Barriers to Latent Entrepreneurship in High Schools in South Africa. Journal of Social Science(JSS) 31(3): 307-318 (2012)

Gordhan, P. (2013). Budget Speech- Minister of Finance. South Africa. Pretoria.

Guillermo Cruces, Andrés Ham and Mariana Viollaz. (2012). Scarring effects of youth unemployment and informality Evidence from Argentina and Brazil. Centre for distributive, Labour and Social Studies(CEDLAS). Latin America. Retrieved April 6, 2013 from www.labor-AL.org.

Hall P. (1997). Unemployment and urban development in Gauteng. Development Southern Africa, 14:3, 395-411 http://www.lo.org lempelm/pubs/WCMS_143349/lang--en/index.htm; http://www.oecd.org/dataoecd/27/57/48732154.pdf

Hunter B. (1998). Addressing youth unemployment: Re-examining social and locational disadvantage within Australian cities, Urban Policy and Research, 16:1, 47-58.

ILO. (2010). Global employment trends for youth, August 2010: special issue on the impact of the global economic crisis on youth I International Labour Office. - Geneva: ILO

ILO. (2013). Global Employment Trends for Youth - 2013 Update, ILO, Geneva. Retrieved April 8, 2013 from http://www.llo.org/empelm/pubs/WCMS_165455/lang--en/index.htm

International Labour Organization. (2003). Jobs for Youth: National Strategies for Employment Promotion, Geneva, Switzerland, 15-16 January 2003 United Nations - Department for Economic and Social.

International Labour Organization. (2008). Global Employment Trends. Geneva.

ILO. (2013). Global Employment Trends for Youth - 2013: A Generation At Risk. ILO, Geneva. Retrieved April 8, 2013 from http://www.ilo.org/empelm/pubs/WCMS_165455/lang--en/index.htm

Jubenkanda R.R. (2003). Labour Economics. Zimbabwe Open University. Harare.

Kahraman, Berna. (2011). "Youth Employment and Unemployment in Developing Countries: Macro Challenges with Micro Perspectives" 
(2011). Graduate Doctoral Dissertations. Paper 36.

Kararach G, Hanson K.T, Léautier F.A. (2011). Regional Integration Policies To Support Job Creation For Africa's Burgeoning Youth Population. African Capacity Building Foundation.

Kezban Çelik. (2008). 'My state is my father': youth unemployment experiences under the weak state welfare provisions of Turkey, Journal of Youth Studies, 11:4, 429-444.

Kouaouci Ali. (2004). Population transitions, youth unemployment, postponement of marriage and violence in Algeria, The Journal of North African Studies, 9:2, 28-45

Langevang Thilde \& Katherine V. Gough. (2009). Surviving through movement: the mobility of urban youth in Ghana, Social \& Cultural Geography, 10:7, 741-756.

Manning C \& P. N. Junankar. (1998). Choosy Youth or Unwanted Youth? A Survey of Unemployment, Bulletin of Indonesian Economic Studies, 34:1, 55-93.

Martins Silvia S. , Weiwei Liu, Sarra L. Hedden , Asha Goldweber, Carla L. Storr , Jeffrey L.(2013). Youth Aggressive/Disruptive Behavior Trajectories and Subsequent Gambling Among Urban Male Youth. Journal of Clinical Child \& Adolescent Psychology, DOI: 10.1080/15374416.2013.764827, 0(0), 1-12, 2013

National Treasury .(2011). Confronting youth unemployment: policy options for South Africa. Discussion Paper. South Africa.

Ndhlovu TP and Spring A. (2013). "The hopeful continent": Economic development and the performance of Sub-Saharan Africa. Forthcoming paper.

Ndhlovu Tidings. (2013). Izikhothane. E-mail Received on 3 February 2013.e-mail address- t.ndhlovu@mmu.ac.uk.

Nigeria. Journal of Sustainable Development in Africa. Vol. 13, No.1, 2011 ISSN: 1520-

Nwokwu Matthew. (2013). The effects of youth Unemployment and its implications on socio-economic stability of Nigerian Democracy. Paper presented during the national Youth Summit at the National Open university of Nigeria. Retrieved April 22, 2013 from www.crimespace.com/profiles/blogs/th... 20-04-2013.

Parkes Jenny \& Anna Conolly. (2011). Risky positions? Shifting representations of urban youth in the talk of professionals and young people, Children's Geographies, 9:3-4, 411-423.

Pervaiz H, Zainab Saleem M. S. and Sajjad M. (2012). Relationship of unemployment with social unrest and psychological distress: An Empirical Study for Juveniles. African Journal of Business Management Vol. 6 (7), pp. 2557-2564.

Presidency of South Africa. (2009). National Youth Policy 2009-2014, Presidency, Pretoria.

Pretoria, South Africa: Government Printers.

Ramcharan, Rodney. (2004). Higher or Basic Education? The Composition of Human Capital and Economic Development, in: IMF Staff Papers Vol. 51 No. 2, International Monetary Fund.

Samara Tony Roshan. (2005). Youth, Crime and Urban Renewal in the Western Cape, Journal of Southern African Studies, 31:1, 209227.

Sembonja H.H.H. ( 2007). The Youth Employment in East Africa: An Integrated Labour Market Perspective. African Integration Review Volume 1, No. 2, July 2007

Simiyu John and Lenah Sambu. (2012). Nature and Type of Government and NGO Interventions in Curbing Unemployment and Underemployment of Urban Youth in Kenya. Journal of Emerging Trends in Educational Research and Policy Studies (JETERAPS) 3(5): 730-736.

Sommers. M. (2003). 'Youth, War, and Urban Africa: Challenges, Misunderstandings, and Opportunities'. In Blair A. Ruble, Joseph S. Tulchin, Diana H. Varat with Lisa M. Hanley. 2003. Youth explosion in developing world cities: approaches to reducing poverty and conflict in an urban age. Woodrow Wilson International Center for Scholars, Washington, D.C. Retrieved April 10,2013 from www.wilsoncenter.org

UNESCO. (2003). Youth Unemployment Meeting the Needs of Youth: An Annotated Bibliography of Research. Wealthiest Nations. Conservation International, Cemex.

World Bank. (2012). Youth and Unemployment in Africa. Report. The World Bank.

Wubie H. (2012). Youth Unemployment And School To Work Transition In Africa: An Ethiopian Perspective. Presented at the Annual International Conference on Productivity, Investment in Human Capital and the Challenge of Youth Employment. Bergamo 18-19, Oct. 2012. 